Journal of Telenursing (JOTING)

Volume 1, Nomor 1, Juni 2019

e-ISSN : 2684-8988

p-ISSN : 2684-8996

DOI: https://doi.org/10.31539/joting.v1i1.500

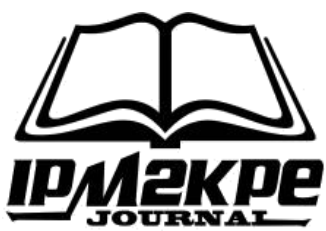

\title{
HUBUNGAN KOMPETENSI IBU, AKTIVITAS FISIK, DAN KONSUMSI JUNK FOOD DENGAN KEJADIAN OBESITAS PADA BALITA
}

\author{
Winarsi Pricilya Molintao ${ }^{1}$, Suhendar Sulaeman ${ }^{2}$, Nyimas Heny Purwanti $^{3}$ \\ Universitas Pembangunan Indonesia Manado ${ }^{1}$ \\ Universitas Muhammadiyah Jakarta ${ }^{2,3}$ \\ winarsi29@gmail.com ${ }^{1}$
}

\begin{abstract}
ABSTRAK
Tujuan penelitian ini yaitu hubungan kompetensi ibu, aktivitas fisik, dan konsumsi makanan junk food dengan kejadian obesitas pada balita di Wilayah Kerja Puskesmas Bahu Kecamatan Malalayang Kota Manado. Penelitian ini merupakan penelitian eksplanatori (Explanatory Research). Hasil penelitian menunjukkan bahwa nila p aktivitas fisik dengan junk food adalah 0,000, aktivitas fisik dengan obesitas 0,016, kompetensi ibu dengan aktivitas fisik 0,000, kompetensi ibu dengan konsumsi junk food 0,011, kompetensi ibu dengan obesitas 0,072 dan konsumsi junk food dengan obesitas 0,0132. Simpulan, tidak ada hubungan antara kompetensi ibu dengan obesitas dengan hasil nilai $p$ value 0,072 . Simpulan, ada hubungan aktivitas fisik dengan konsumsi junk food, ada hubungan aktivitas fisik dengan obesitas, ada hubungan kompetensi ibu dengan aktivitas fisik, ada hubungan kompetensi ibu dengan konsumsi junk food.
\end{abstract}

Kata Kunci: Aktivitas Fisik, Kompetensi Ibu, Konsumsi Junk Food, Obesitas

\begin{abstract}
The purpose of this study is the relationship between maternal competence, physical activity, and consumption of junk food with the incidence of obesity in children under five in the work area of the Shoulder Health Center, Malalayang District, Manado City. This research is an explanatory research (Explanatory Research). The results showed that the value of physical activity with junk food was 0.000, physical activity with obesity was 0.016, competence of mothers with physical activity was 0.000, competence of mothers with junk food consumption was 0.011, competence of mothers with obesity was 0.072 and consumption of junk food with obesity was 0.0132. In conclusion, there is no relationship between maternal competence and obesity with a $p$ value of 0.072. In conclusion, there is a relationship between physical activity and junk food consumption, there is a relationship between physical activity and obesity, there is a relationship between maternal competence and physical activity, there is a relationship between maternal competence and consumption of junk food.
\end{abstract}

Keywords: Physical Activity, Maternal Competence, Junk Food Consumption, Obesity 


\section{PENDAHULUAN}

Obesitas atau kelebihan berat badan dikarenakan terjadinya kelebihan akumulasi lemak tubuh yang relatif terhadap masa tubuh tanpa lemak (Wong et al., 2009). Banyak orang tua beranggapan bahwa balita yang gemuk akan terlihat lebih lucu, dianggap sangat sehat dan menggemaskan, dibandingkan balita yang berat badannya pas atau ideal. Upaya untuk menyediakan makanan sehat dan untuk mendorong aktivitas fisik harus dimulai sejak dini untuk membantu anak mencapai kesehatan optimal (Hockenberry, 2013). Menurut World Health Organization (WHO) (2015) obesitas yakni salah satu dari 10 kondisihampir diseluruh duniadan merupakan yang ke 5 kondisi yang berisiko di Negara berkembang. Prevalensi obesitas di seluruh dunia baik di negara berkembang maupun negara yang sedang berkembang telah meningkat. Sebanyak 42 juta anak secara global mengalami kegemukan 31 juta diantaranya di Negara berkembang (Purnamasari, 2018).

Di Indonesia, pemantauan status gizi tahun 2016 Ditjen Kesehatan Masayarakat Kemenkes RI 2017 memperlihatkan bahwa angka obesitas pada balita di Indonesia mencapai 14\%, sedangkan untuk kelompok anak berusia 15 tahun keatas angka obesitas mencapai 19,1\%. Presentase anak balita usia 0-59 bulan memiliki status gizi yag menggunakan indeks BB/TB pada setiap Provinsi di tahun 2015-2016 Sulawesi Utara berada pada posisi ke 3 dengan balita gemuk $(6,2 \%)$, sedangkan balita gemuk yang terbanyak di Provinsi DKI Jakarta $(8,1 \%)$, dan Bangka Belitung $(6,8 \%)$ (Kemenkes RI, 2017).

Masalah gizi di Indonesia saat ini memasuki masalah gizi ganda. Artinya bahwa masalah gizi kurang belum dapat teratasi sepenuhnya, tetapi saat ini mulai muncul masalah pada anak dengan gizi lebih. Pada kasus gizi kurang seringkali dihubungkan dengan jenis penyakit infeksi, sedangkan gizi lebih atau obesitas cenderung merupakan awal sinyal dari penyakit degeneratif/penyakit non infeksi yang saat ini banyak terjadi hampit diseluruh daerah, dan kota, maupun di pelosok di Indonesia (Ginanjar, 2009).

Beberapa faktor yang menyebakan obesitas pada anak maupun balita belum dapat diketahui secara pasti hingga saat ini. Namun berbagai penelitian ilmiah menunjukkan bahwa penyebab kegemukan dan obesitas bersifat multifaktor antara lain kurangnya pengetahuan orang tua.Persepsi kebanyakan orang tua menganggap bahwa jika anak mereka gemuk berarti dia akan terlihat lucu, menggemaskan, dan bahagia, dari ciri seperti itu maka orang tua beranggapn bahwa anak mereka sehat, sehingga hal ini yang menjadi penyebab obesitas ketika anak tumbuh dan dewasa (Diana et al., 2013). Perkembangan teknologi yang pesat juga berkontribusi peningkatan prevalensi kegemukan, sehingga tanpa disadari akhirnya menggiring anak balita untuk memiliki gaya hidup yang sedentary yakni hidup yang santai yakni anak lebih memilih menghabiskan waktu di depan televisi atau bermain gadget daripada beraktivitas aktif, pola asupan makanan meningkat, dan lebih memilih untuk lebih banyak makanan junk food (Geeta \& Mishra, 2013).

Dampak yang terjadi jika balita mengalami obesitas antara lain yaitu cenderug dapat mengakibatkan terkena mellitus tipe II, meningkatnya nilai kolestrol sehingga mengakibatakan tekanan drarah meningkat dan dapat menyebakan penyakit jantung, nafas berhenti saat tidur (sleep арпиe), gangguan ortopedi, penyakit asma dan hati (Fikawati \& Veratamala, 2017).

Anak dengan obesitas cenderung akan mengalami peningkatan tekanan darah sehingga berpengaruh pada denyut jantung, sekitar 20-30\% anak dengan obesitas menderita hipertensi (Verani, 2013). Pada anak obesitas sering dijumpai dengan gejala 
mengorok. Penyebab tersebut yakni terjadinya penebalan jaringan lemak di daerah dinding dada perut sehingga menganggu proses pergerakan dinding dada dan diafrgama, sehingga terjadi penurunan volume torakal adomen dan menyebabkan beban kerja otot pernapasan meningkat.

Siti (2008) menerangkan bahwa pengetahuan orang tua merupakan salah satu faktor yang mempengaruhi status gizi balita yang baik tentang masalah kesehatan dan pengasuhan anak dapat memperbaiki sikap, perilaku ibu sehingga dalam pengasuhan dan perbaikan gizi balita dapat terpenuhi sesuai pertumbuhan balita. Pengetahuan ibu, sikap ibu, dan perilaku ibu merupakan satu kompetensi yang dimiliki ibu dalam pemenuhan gizi balita. Sedangkan. Penelitian yang telah dilakukan di Amerika hampir $50 \%$ dengan tingkat aktivitas yang kurang menyebabkan penumpukan lemak tubuh yang berlebih dibanding dengan yang memiliki aktivitas yang tinggi, dikarenakan aktivitas fisik merupakan hal utama dalam emnjaga keseimbangan metabolisme terutama dalam penyimpanan dan pengeluaran energi (Musa, 2010).

Pola hidup yang serba santai dan mudah dapat membuat tubuh menjadi kurang bergerak atau sedikit menggunakan tenaga untuk melakukan aktivitas sehari-hari. Pada umumnya makanan yang telah dikonsumsi sebagian besar seharusnya dibakar agar tidak menumpuk menjadi lemak. Lemak yang bertumpuk secara terus-menerus dapat membuat ukuran tubuh menjadi terus bertambah (Dewi, 2013). Mathis \& Jackson (2013) mengatakan bahwa mengkonsumsi junk food berlebihan dapat meningkatkan masalah obesitas pada anak-anak, yakni junk food banyak mengandung tinggi lemak jenuh dan gula tetapi rendah serta dan tentu saja pasti memiliki konsep gizi yang tidak seimbang, sehingga berdampak negating pada status gizi anak.

Di Wilayah Kerja Puskesmas Bahu Kota Manado Provinsi Sulawesi Utara, sejak bulan Januari tahun 2017 hingga bulan Desember tahun 2017 didapatkan data, dari 1.425 balita yang ditimbang 89 balita $(5,65 \%)$, diantaranya laki-laki sebanyak 55 balita $(8,7 \%)$, perempuan sebanyak 31 balita $(5,6 \%)$ mengalami gizi lebih (obesitas) dan tertinggi di wilayah kleak (Data Profil Puskesmas Bahu, 2017). Berdasarkan studi pendahuluan dari peneliti melalui wawancara dan observasi terhadap orang tua balita obesitas didapatkan dari 10 anak dengan obesitas 6 diantaranya sering mengkonsumsi junk food apalagi di dukung dengan adanya aplikasi go food online, sehingga memudahkan orang tua yang sibuk untuk memberi makan anaknya sesuai dari keinginan anak tersebut, dan kebanyakan dari balita tersebut lebih memilih makanan junkfood.

Asupan makanan yang lebih dari tiga kali dalam sehari sering juga anak balita dikarenakan keuntungan dari aplikasi go food online sehingga frekuensi untuk makan sehari bisa lebih dari 3 kali di ikuti dengan cemilan, dan jajanan makanan yang dapat dipesan dengan mudah. Sedangkan 4 anak lainnya sering makan lebih dari 3 kali dalam sehari tetapi, untuk melakukan aktivitas bermain dilinkungan luar rumah atau dengan teman sebaya, maupun diajak oleh keluarga bermain anak lebih memilih bermain gadget ataupun menonton youtube sambil duduk, tiduran kadang mengemil makanan cemilan seperti gorengan, ataupun snack dan kegiatan tersebut dilakukan bisa lebih dari 5 jam dalam sehari.

\section{METODE PENELITIAN}

Jenis penelitian yang digunakan adalah penelitian eksplanatori (Explanatory Research). Eksplanatori merupakan penelitian yang menjelaskan hubungan kausal antara variabel yang mempengaruhi hipotesis. Di dalam penelitian eksplanatori, 
pendekatan yang dipakai pada penelitian ini adalah metode survei. Metode yang dugunakan adalah dengan metode survey analitik. Jumlah sampel dalam penelitian ini adalah 98 Balita.Adapun kriteria inklusinya adalah Balita di Wilayah kerja Puskesmas Bahu Kota Manado. Orang tua balita bersedia menjadi responden. Alat pengumpulan data menggunakan lembar kuesioner dalam penelitian ini teknik analisis yang digunakan adalah SEM (structural equation modelling). Aplikasi perangkat lunak statistika SEM yang digunakan adalah program smartPLS 3.0. Alternatif teknik SEM (structural equation modelling) adalah analisis PLS (partial least square).

\section{HASIL PENELITIAN}

Karakteristik responden

Tabel. 1

Distribusi Responden Berdasarkan Jenis Kelamin Balita, Pendidikan Ibu, Penghasilan Orang Tua, Status Gizi, Kompetensi Ibu, Aktivitas Fisik Balita, dan Konsumsi Junk Food $(\mathrm{n}=98)$

\begin{tabular}{lcc}
\hline \multicolumn{1}{c}{ Variabel } & Frekuensi & Presentase (\%) \\
\hline Jenis Kelamin Balita & 59 & 60,2 \\
Perempuan & 39 & 39,8 \\
Laki-Laki & 98 & 100 \\
\hline Total & 4 & 4,1 \\
\hline Pendidikan Ibu & 41,8 \\
SMP & 41 & 54,1 \\
SMA & 53 & 100 \\
D3/S1/S2 & 98 & \\
\hline Total & & 16,3 \\
\hline Penghasilan & 16 & 83,7 \\
<UMR & 82 & 100 \\
$\geq$ UMR & 98 & 26,5 \\
\hline Total & & 73,5 \\
\hline Status Gizi & 26 & 100 \\
Normal & 72 & 73,5 \\
Gemuk & 98 & 26,5 \\
\hline Total & & 100 \\
\hline Obesitas & 72 & 58,2 \\
Obesitas & 26 & 41,8 \\
Tidak Obesitas (Normal) & 98 & 100 \\
\hline Total & & \\
\hline Kompetensi Ibu & 57 & 61,2 \\
Baik & 41 & 37,8 \\
Kurang Baik & 98 & 100 \\
\hline Total & 61 & 39,8 \\
\hline Aktivitas Fisik & 37 & 100 \\
Ringan & 98 & \\
Sedang & 39 & \\
\hline Total & 59 & \\
\hline Konsumsi Junk Food & 98 & \\
Sidak Sering & & \\
\hline Total & & \\
\hline & & \\
\hline & & \\
\hline
\end{tabular}


Berdasarkan tabel 1 dapat diketahui bahwa yang terbanyak yakni responden balita yang berjenis kelamin perempuan sebesar 60,2\% (59 balita), responden ibu dengan pendidikan D3/S1/S2 sebesar 54,1\% (53 ibu responden), responden orang tua dengan penghasilan $\geq$ UMR sebesar $83,7 \%$ (82 responden), balita dengan status gizi gemuk sebesar 73,5\% (72 responden), responden ibu dengan kompetensi kurang baik sebesar $58,2 \%$ (57 responden), aktivitas fisik balita ringan sebesar 62,2\% (61 responden), responden balita dengan konsumsi junk food sering sebesar 60,2\% (59 responden).

Tabel. 2

Hubungan Aktivitas Fisik dengan Konsumsi Junkfood dan Obesitas, Kompetensi Ibu dengan Aktivitas Fisik, Konsumsi Junkfood dan Obesitas, serta Konsumsi Junkfood dengan Obesitas ( $\mathrm{n}=98)$

\begin{tabular}{|c|c|c|c|c|c|}
\hline & $\begin{array}{c}\text { Orginal } \\
\text { Sample } \\
\text { (O) }\end{array}$ & $\begin{array}{c}\text { Sample } \\
\text { Mean (M) }\end{array}$ & $\begin{array}{c}\text { Standard } \\
\text { Deviation } \\
(\text { STDREV) }\end{array}$ & $\begin{array}{c}\mathrm{T} \\
\text { Statistics } \\
((\mid \mathrm{O} / \mathrm{ST} \\
\mathrm{DEV} \mid)\end{array}$ & $\begin{array}{c}\mathrm{P} \\
\text { Value }\end{array}$ \\
\hline $\begin{array}{l}\text { Aktivitas Fisik -> } \\
\text { Konsumsi Junk Food }\end{array}$ & 0,438 & 0,440 & 0,082 & 5,374 & 0,000 \\
\hline $\begin{array}{l}\text { Aktivitas Fisik -> } \\
\text { Obesitas }\end{array}$ & $-0,306$ & $-0,320$ & 0,127 & 2,413 & 0,016 \\
\hline $\begin{array}{l}\text { Kompetensi Ibu -> } \\
\text { Aktivitas Fisik }\end{array}$ & $-0,296$ & $-0,313$ & 0,074 & 3,963 & 0,000 \\
\hline $\begin{array}{l}\text { Kompetensi Ibu -> } \\
\text { Konsumsi Junk Food }\end{array}$ & $-0,238$ & $-0,252$ & 0,093 & 2,555 & 0,011 \\
\hline $\begin{array}{l}\text { Kompetensi Ibu -> } \\
\text { Obesitas }\end{array}$ & $-0,189$ & $-0,190$ & 0,105 & 1,804 & 0,072 \\
\hline $\begin{array}{l}\text { Konsumsi Junk Food - } \\
>\text { Obesitas }\end{array}$ & 0,203 & 0,222 & 0,134 & 1,508 & 0,132 \\
\hline
\end{tabular}

\section{Hubungan Kompetensi Ibu dengan Aktivitas Fisik}

Hasil pengujian hipotesis pertama menunjukkan bahwa hubungan kompetensi ibu dengan aktivitas fisik menunjukkan nilai $T$ statistic sebesar 3,963 $(>1,96)$ dan $P$ value sebesar $0,000(<0,05)$. Maka dapat disimpulkan ada hubungan antara kompetensi ibu dengan aktivitas fisik.

\section{Hubungan Kompetensi Ibu dengan Konsumsi Junk Food}

Hasil pengujian hipotesis kedua menunjukkan bahwa hubungan kompetensi ibu dengan konsumsi junk food menunjukkan nilai $T$ statistic sebesar 2,555 (> 1,96) dan $P$ value sebesar 0,011 (<0,05). Maka dapat disimpulkan ada hubungan antara kompetensi ibu dengan konsumsi junk food.

\section{HubunganAktfitas Fisik dengan Konsumsi Junk Food}

Hasil pengujian hipotesis ke tiga menunjukkan bahwa hubunganaktifitas fisikdengan konsumsi junk food menunjukkan nilai $T$ statistic sebesar 5,374 $(>1,96)$ dan $P$ value sebesar $0,000(<0,05)$. Maka dapat disimpulkan ada hubungan antara aktivitas fisik dengan konsumsi junk food. 


\section{Hubungan Kompetensi Ibu dengan Obesitas}

Hasil pengujian hipotesis ke empat menunjukkan bahwa hubungan kompetensi ibu dengan obesitas menunjukkan nilai $T$ statistic sebesar $1,804(<1,96)$ dan $P$ value sebesar 0,072 (>0,05). Maka dapat disimpulkan tidak ada hubungan antara kompetensi ibu dengan obesitas.

\section{HubunganAktivitas Fisik dengan Obesitas}

Hasil pengujian hipotesis ke lima menunjukkan bahwa hubungan aktivitas fisik dengan obesitas menunjukkan nilai $T$ statistic sebesar 2,413 $(>1,96)$ dan $\mathrm{P}$ value sebesar $0,016(<0,05)$. Maka dapat disimpulkan ada hubungan antara aktivitas fisik dengan obesitas.

\section{Hubungan Konsumsi Junk Food dengan Obesitas}

Hasil pengujian hipotesis ke enam menunjukkan bahwa hubungan konsumsi junk food dengan obesitas menunjukkan nilai $T$ statistic sebesar $1,508(<1,96)$ dan $P$ value sebesar 0,132 (>0,05). Maka dapat disimpulkan tidak ada hubungan antara konsumsi junk food terhadap obesitas.

\section{PEMBAHASAN}

\section{Karakteristik Responden}

Berdasarkan hasil penelitian didapatkan karakterisitik responden yang terbanyak yaitu responden balita berjenis kelamin perempuan, responden ibu dengan pendidikan $\mathrm{D} 3 / \mathrm{S} 1 / \mathrm{S} 2$, responden orang tua dengan penghasilan $\geq \mathrm{UMR}$, balita dengan status gizi gemuk, responden ibu dengan kompetensi kurang baik, aktivitas fisik balita ringan, responden balita dengan konsumsi junk food sering.

Anak perempuan lebih mungkin mengalami obesitas ketimbang anak laki-laki. Temuan ini berdasarkan hasil pengamatan selama 20-tahun oleh para ilmuwan di Glasgow University, Skotlandia. Penelitian melibatkan hampir 1.500 keluarga di Skotlandia Barat dan menemukan bahwa sebesar 24 persen anak akan mengalami obesitas sama seperti orang tua mereka. Hanya 9 persen saja anak yang tidak mengalami kegemukan dari orangtua dengan obesitas. Data juga menunjukkan bahwa dari 17 persen ibu dengan obesitas, nantinya akan berisiko mempunyai anak perempuan dengan obesitas pula, yakni sebesar 20 persen. Angka perbedaan ini jauh lebih besar lebih besar jika melihat proporsi antara ayah dengan anak laki-laki atau ibu dengan anak laki-laki. Riset menyimpulkan bahwa perempuan lebih cenderung memiliki berat badan yang mirip dengan ibu mereka, dan para ahli mempercayai bahwa hal ini bisa disebabkan karena kurangnya keterampilan ibu dalam mengolah makanan dan pilihan makanan yang salah (Widyawati, 2014).

\section{Hubungan Kompetensi Ibu dengan Aktivitas Fisik}

Berdasarkan hasil penelitian didapatkan adanya pengaruh antara kompetensi ibu terhadap aktivitas fisik. Hal ini berarti apabila kompetensi ibu seperti pengetahuan, sikap, perilaku ibu baik maka aktivitas fisik anak pun baik.

Kompetensi merupakan ketrampilan yang terdiri dari pengetahuan, sikap, dan perilaku yang tercermin melalui kebiasaan berpikir dan bertindak ynag sifatnya berkembang, kontinyu (terus-menerus) serta didapatkan setiap waktu. Kebiasaan untuk berpikir dan bertindak secara konstan, dan konsisten serta dilakukan secara terusmenerus dapat membuat seorang menjadi kompoten. Sehingga kompetensi merupakan 
kemampuan diri seseorang untuk menunjukkan dan mengaplikasi kemampuan ketrampilan dalam kehidupan nyata.

Aktivitas fisik merupakan gerakan tubuh oleh otot tubuh dan system organ dalama tubuh membantu dalam proses pengeluaran energi. Aktivitas fisik yang teratur bermanfaat untuk anak usia balita maupun prasekolah, manfaatnya dapat berkembangnya kekuatan dan ketahanan otot untuk membangun dan mendorong harga diri, meningkatkan stabilitas dari tubuh, meningkatkan kekuatan otot, jantung dan tulang, mengembangkan ketrampilan untuk mengontrol obyek tertentu, meningktakan perkembangan pengenalan terhdapa benda, bentuk, dan warna dan ketahanan dalam sistem kardiovaskuler.

Patricia Banner mengungkapkan bahwa untuk mengevaluasi kesehatan anak balita, pertumbuhan dan perkembangan maka diperlukan peranan penting dari orang tua pengetahuan, sikap, perilaku merupakan dasar utama ibu untuk meningkatan kemampuan aktivitas fisik balita.

Kompetensi baik yang dimiliki ibu tentang pentingnya aktivitas fisik balita dapat membantu anak untuk terhindar dari masalah obesitas. Pemberian edukasi pentingnya hidup sehat dan berolahraga yang cukup sangat diperlukan. Peranan penting orang tuayakni mengawasi jadwal anak terutama dalam aktivitas keseharian anak.

\section{Hubungan Kompetensi Ibu dengan Konsumsi Junk Food}

Berdasarkan hasil penelitian didapatkan ada pengaruh antara aktivitas fisik terhadap konsumsi junk food. Kompetensi merupakan keterampilan yang terdiri dari pengetahuan, sikap, dan perilaku yang dicerminkan dalam kebiasaan berpikir dan bertindak yang sifatnya berkembang, dinamis dan terus-menerus. Kebiasaan berpikir serta bertindak secara konstan, dan jika dilakukan secara konsisten dan terus menerus maka akan membuat orang tua semakin kompoten. Sehingga kompetensi merupakan kemampuan yang ada pada diri seseorang untuk menunjukkan dan mengaplikasikan ketrampilannya tersebut didalam kehidupan nyata.

Kompetensi yang dimiliki ibu akan mempengaruhi konsumsi pangan melalui cara pemilihan bahan pangan. Semakin baik komptensi ibu cenderung semakin baik dalam memilih kualitas dan kuantitas bahan makanan. Memiliki kompetensi yang baik meembuat ibu semakin pandai dalam memilih, dan mengolah bahan makanan, dan tentu saja proses distribusinya akan lebih baik karena makanan akan tergolong sehat dan diberikan pada waktu yang tepat. Disamping itu kompetensi ibu juga mencakup tentang cara ibu menyajikan makananyang sehat dengan cara ekonomis, maupun kebiasaan aktivitas yang baik pada balita.

Banyak ibu memberikan makanan pada anak berupa permen dan jajanan lainnya, sebagai reward untuk mendorong anak melakukan perilaku yang diharapkan ibu. Praktik ini dapat mengembangkan makna simbolis, sehingga anak menggunakan makanan sebagai penghargaan, serta membuat nyaman, disat mengahadapi perasaan marah, bosan, depresi, dan kesepian (Wong et al., 2009).

Penelitian lain yang dilakukan oleh Ashlesha (2013) menunjukkan hasil bahwa intervensi pendidikan kesehatan dan gizi pada orang tua atau keluarga yang mempunyai anak balita akan merubah perilaku dari keluarga itu terutama dalam hal pengasuhan dan memberikan makanan pada anak sehingga akan dapat meningkatkan status gizi balita di keluarga itu. Tetapi dari hasi penelitian di Puskesmas bahu cenderung orang tua balita mengabaikan tentang pentingnya edukasi pendidikan yang diberikan di Puskesmas sehingga kompetensi ibu sebagian besar kurang baik. 
Patricia Banner mengungkapkan masalah yang dihadapi oleh anak balita merupakan hasil dari respon atau perilaku orangtua selaku pemberi asuhan pada anak. Sehingga respon dari orang tua berdampak pada anak orang tua dengan kompetensi yang baik mampu menyediakan makanan yang sehat pada anak tetapi orang tua dengan kompetensi yang kurang cenderung mnyediakan makanan yang kurang bergizi, tetapi orang tua dengan kompetensi yang kurang cenderung memeberikan makanan yang cepat saji, ditambah lagi dengan jaman yang semakin modern dan semakin mempermudah setiap orang mendapatkan makanan sehingga makanan siap saji junk food yang menjadi alternatif pilihan dari keluarga.

\section{Hubungan Aktivitas Fisik dengan Konsumsi Junk Food}

Berdasarkan hasil penelitian didapatkan ada pengaruh antara aktivitas fisik terhadap konsumsi junk food. Aktivitas fisik yaitu gerakan tubuh yang dapat meningkatkan proses pengeluaran energi atau pembakarana kalori dalam tubuh (Kemenkes RI, 2015).

Junk food merupakan makanan yangkurang mengandung nutrisi yang dibutuhkan oleh tubuh agar tetap sehat. Akibatnya, akan merasa lelah dan kekurangan energi yang dibutuhkan oleh tubuh yang digunakan dalam aktivitas sehari-hari. Tingginya kandungan gula dalam makanan cepat saji berdampak pada system metabolism tubuh akan tidak terkendali. Ketika kita mengkonsumsi gula maka pankeras akan mengeluarkan insulin dalam jumlah yang tinggi untuk mencegah kenaikan kadar gula dalam darah. Makan cepat saji tidak mengandung protein dan karbohidrat yang cukup dan baik bagi tubuh, sehingga kadar gula darah akan turun secara tiba-tiba ketika kita makan, dan hali ini dapat mempengaruhi tingkat emosi akan mudah marah, dan lelah.

Konsumsi junk food meski lebih tetapi diimbangi dengan kegiatan aktivitas fisik yang banyak, maka kecenderungan mengalami kegemukan pada balita akan semakin kurang, tetapi sebaliknya jika balita yang sering mengkonsumsi junk food tanpa diimbangi aktivitas fisik yang lebih sebaliknya lebih cenderung untuk mengalami kenaikan berat badan.

Patricia banner mengungkapkan bahwa perilaku balita dapat bersikap adaptif maupun maladaptive tergantung pada respon dan perilaku dari ibu balita, ibu balita yang memiliki kesadaran tentang pentingnya kesehatan balita cenderung tidak akan membiarkan anaknya asik bermain games atau menonton dengan makan makanan junk food. Tetapi ibu balita yang cenderung sibuk mungkin lebih menginginkan anaknya demikian oleh sebab itu kebanyakan anak balita lebih memilih untuk makan sambil bermain gadget dibanding makan dulu selesai makan memilih untuk bermain dengan teman-teman sebayanya.

\section{Hubungan Kompetensi Ibu dengan Obesitas}

Berdasarkan hasil penelitian didapatakan bahwa tidak ada pengaruh antara kompetensi ibu terhadap obesitas. Obesitas merupakan suatu kondisi yang kompleks dan mungkin melibatkan berbagai pengaruh, termasuk faktor metabolik, hipotalamus, hereditas, social, budaya dan psikologis. Kurang dari 5\% obesitas pada masa kanakkanak dihubungkan dengan penyakit utama seperti hipertiroidisme, hipekortikoidisme adrenal, hiperinsulinisme, dan disfungsi atau mengalami kerusakan pada system saraf pusat (Hockenberry, 2013). 
Anak dengan obesitas cenderung akan mengalami peningkatan tekanan darah sehingga berpengaruh pada denyut jantung, sekita 20-30\% anak dengan obesitas menderita hipertensi (Verani, 2013). Pada anak obesitas sering dijumpai dengan gejala menggorok. Penyebab tersebut yakni terjadinya penebalan jaringan lemak di daerah dinding dada perut sehingga menganggu proses pergerakan dinding dada dan diafrgama, sehingga terjadi penurunan volume torakal adomen dan menyebabkan beban kerja otot pernapasan meningkat.

Metabolisme atau glukosa berperan penting dalam pengaturan deposit lemak, dan beberapa teori telah dikembangkan untuk menjelaskan variasi metabolisme di antara individu. Salah satu teori mengemukakan adanya peningkatan efesiensi metabolik pada individu obesitas memfasilitasi penyimpanan dan retensi lemak (Wong et al., 2009).

Kompetensi ibu merupakan salah satu faktor yang menyebabkan obesitas. Kompetensi adalah ketrampilan yang terdiri yang terdiri dari pengetahuan, sikap, dan perilaku yang akan tercermin dalam kebiasaan berpikir dan bertindak dati orang tua. Sehingaa akan berkembang secara dinamis dan terus menerus dan terjadi dalam setiap waktu. Jika orang tua memiliki kebiasaan berpikir dan bertindak dengan demikian secara konstan dan konsisten maka hal itu akan yang akan membuat ibu menjadi kompoten. Sehingga dapat mengaplikasikan keterampilan tersebut dalam kehidupan sehari-hari.

\section{Hubungan Aktivitas Fisik dengan Obesitas}

Berdasarkan hasil penelitian didapatkan bahwa ada pengaruh antara aktivitas fisik terhadap obesitas. Pada anak umur 2-5 tahun, aktivitas fisik lebih pada aktivitas bermain. Permainan untuk membuat anak aktif bergerak sangat beragam. Permainan yang dilakukan anak selain untuk menggerakan otot-otot dalam tubuh anak juga dapat melatih anak untuk perkembangan motoric kasar dan motorik halus, dan dapat meningkatkan anak dalam kemampuannya berpikir dan menja ga keseimbangan tubuh. Aktivitas bermain yang dilakukan oleh anak dapat dilakukan secara individual, juga secara berkelompok seperti permainan petak umpek, lompat tali, dan dapat melatih kemampuan komunikasi dan sosial anak, sehingga akan tumbuh rasa peduli dan empati pada anak-anak yang menjadi teman bermainnya, dan melatih kebersamaan dan kerja sama antar sesama teman.

Aktivitas bermain yang dilakukan secara teratur dapat mengurangi resiko penumpukan lemak yang berlebih pada tubuh anak, sehingga resiko obesitas pada anak terhindarkan. Pengaruh yang bermakna dari aktivitas fisik yang dalan proses pengeluaran energi, sehingga peningkatan akativitas dapat meningkatkan laju metabolism membuat pembakar lemak lebih baik, dan menghindarkan anak dari resiko obesitas.

Aktivitas fisik merupakan salah satu faktor yang berpengaruh pada terjadinya obesitas. Hasil metabolisme tubuh yang berupa energi digunakan untuk melakukan aktivitas sehari-hari. Pada orang dengan berat badan yang normal, ia akan mengeluarkan sepertiga energi untuk melakukan aktivitas fisik tetapi untuk anak dengan berat badan yang berlebih ia harus sering untuk melakukan aktivitas fisik yang lebih untuk mengurangi simpanan lemak yang terdapat di jaringan adipose. Kurangnya aktivitas fisik menyebabkan lemak yang tersimpat tidak dapat dijadikan sebagi energi. sehingga pada anak yang kurang beraktivitas dengan pola makan konsumsi tinggi cenderung menjadi gemuk. Kurangnya aktivitas fisik dapat mempengaruhi terjadinya obesitas (Nuraini, 2015). Obesitas yang terjadi pada anak tidak hanya dipengaruhi oleh 
aktivitas fisik saja, namun dipengaruhi juga oleh faktor genetik, biologis, sosial kultural, dan psikologis, serta lingkungan.

Menurut penelitian Wijaya \& Putri (2013) nilai Physical Activity Level (PAL) pada anak usia pra sekolah (3-5 tahun) tergolong rendah karena kurangnya aktivitas fisik dan cenderung menghabiskan waktu dengan menonton tv, bermain gadget, berjalan-jalan ke pusat perbelanjaan, berbeda dengan anak-anak prasekolah yang mengambil kegiatan renang dan futsal yang memanfaatkan pergerakan otot dan membantu pembakaran kalori dan energi sehingga anak-anak tersebut memiliki nilai PAL tinggi.

Penelitian ini sejalan dengan Zamzani et al., (2016) menunjukkan bahwa nilai $\mathrm{p}$ value 0,009 $(<0,05)$ dengan nilai OR 5,69 (95\% CI: 1,42-22,65), dengan kata lain anak yang melakukan aktivitas sedang-berat $\leq 1$ jam/hari berpeluang 5 kali lebih besar untuk mengalami obesitas daripada anak dengan aktivitas sedang-berat $>1$ jam/hari.

\section{Hubungan Konsumsi Junk Food dengan Obesitas}

Berdasarkan hasil penelitian didapatkan bahwa tidak ada pengaruh antara konsumsi junk food terhadap obesitas. Makanan jenis junk food telah mengalami proses masak lebih dahulu, sehingga zat gizi yang penting telah hilang banyak seperti vitamin dan mineral.

Beberapa faktor yang menyebakan obesitas pada anak maupun balita belum dapat diketahui secara pasti hingga saat ini. Namun berbagai penelitian ilmiah menunjukkan bahwa penyebab kegemukan dan obesitas bersifat multifaktor antara lain kurangnya pengetahuan orang tua.Persepsi kebanyakan orang tua menganggap bahwa jika anak mereka gemuk berarti dia akan terlihat lucu, menggemaskan, dan bahagia, dari ciri seperti itu maka orang tua beranggapn bahwa anak mereka sehat, sehingga hal ini yang menjadi penyebab obesitas ketika anak tumbuh dan dewasa (Diana et al., 2013).

Makanan fast food dan minuman bersoda kebanyakan di masyarakat dianggap sebagai makanan yang buruk yang menyebabkan obesitas, Tetapi bebebrapa peneliti beranggapan berbeda, sesuai dengan peneltian di Universitas Cornel didapatkan bahwa makanan fast food dan minuman bersoda bukan penyebab obesitas. Dilansir bahwa tidak ada perbedaan anatar orang yang makan banyak dan yang gemar makan makanan fast food dan soda. Penelitian tersebut yang dilakukan oleh Profesor David Just dan Brian Wansink diterbitkan melalui jurnal Obesity Sciencen \& Pratice, menganalisis data Amerika (2007-2008) dengan 5.000 responden, dengan dibandingkan data terbaru (2013-2014), ditemukan bahwa minduman bersoda, fast food, dan permen tidak berdampak pada boddy mass index, yang artinya makanan dan minuman tersebut tidak menjadi penyebab kenaikan berat badan yang menyebabkan obesitas. Hal ini dibuktika dari 95\% responden yang suka minum bersoda dan mengkonsumsi fast food, tetap mmiliki badan kurus. Jadi didapatkan bahwa obesitas terjadi dikarenakan jumlah kalori yang lebih dikonsumsi.

\section{SIMPULAN}

Hasil penelitian didapatkan bahwa tidak ada hubungan antara kompetensi ibu dengan obesitas, tidak ada hubungan anatar konsumsi junk food dengan obesitas, ada hubungan aktivitas fisik dengan konsumsi junk food, ada hubungan aktivitas fisik dengan obesitas, dan ada hubungan kompetensi ibu dengan aktivitas fisik. 


\section{SARAN}

Diharapkan pada penelitian ini ibu balita untuk lebih terlibat aktif dalam kegiatankegiatan edukasi kesehatan yang telah dicanangkan dan dilakukan oleh puskesmas saat melakukan kunjungan di Puskesmas. Sebaiknya ibu juga lebih memperhatikan akan kebutuhan gizi yang baik untuk anak, dan meningkatkan keinginan anak untuk lebih aktif lagi bermain bersama teman-teman sebayanya dibanding menghabiskan waktu bermain gadget dan menonton tv di rumah, kalaupun sedang di sekolah diharapkan orang tua tidak memberikan anak untuk membawa gadget.

\section{DAFTAR PUSTAKA}

Ashlesha, A. (2013). Junk Food in Schools and Childhood Obesity. Journal Internasional NIH Public Access

Dewi, D. (2013). Studi Deskriptif: Presepsi dan Perilaku Makan Buah dan Sayuran pada Anak Obesitas dan Orang Tua. Jurnal Ilmiah Mahasiswa Universitas Surabaya, 2(1)

Diana, R., Yuliana, I., Yasmin, G., \& Hardinsyah, H. (2013). Faktor Risiko Kegemukan pada Wanita Dewasa Indonesia Gizi dan Pangan. Journal Kesehatan, 8(1). http://jesl.journal.ipb.ac.id/index. php/jgizipangan/article/viewFile/ 7226/5647

Fikawati, S., \& Veratamala, V. (2017). Gizi Anak dan Remaja. Depok: PT Raja Grafindo Persada

Geeta, A., \& Mishra, S. (2013). Effects of Junk Food \& Beverages on Adolescen't Health a Review Article. IOSR Journal of Nursing and Health Science

Ginanjar, G. (2009). Obesitas pada Anak. Yogyakarta: B'Firs. PT Bintang Pustaka

Hockenberry, H., \& Wilson, W. (2013). Wong's Essentials of Pediatric Nursing. Library of Congress Cataloging in Publication Data: America

Kemenkes RI. (2017). Profil Kesehatan Indonesia Tahun 2016. Jakarta: Kementrian Kesehatan Republik Indonesia

Mathis, R. L., \& Jackson, J. H. (2013). Human Resources Management. Thomson Learning

Musa, M. (2010). Faktor Risiko Obesitas pada Remaja. Jurnal Kesehatan, 1(2), 133140

Nuraini, B. (2015). Risk Fators of Hypertension. Faculty of Medicine, University of Lampung, 4(5), 11

Purnamasari, P. (2018). Panduan Gizi dan Kesehatan Anak Sekolah. Yogyakarta: Andi

Siti, D. D. (2008). Hubungan antara Pengetahuan, Sikap, dan Perilaku Ibu dengan Status Gizi Anak Balita. Universitas Sebelas Maret Surakarta

Verani, P. (2013). Perbedaan Prestasi Belajar antara Anak Sekolah Dasar Penderita Obesitas dan Status Gizi Normal. Jurnal Kesehatan, 3(2), 12-14

Widyawati, W. (2014). Faktor-Faktor yang Berhubungan dengan Obesitas pada Anak Sekolah Dasar Usia 6-14 tahun di SD. Budi Mulia 2 Yogyakarta. Naskah Publikasi Journal Skripsi, 11(4), 170-190

Wijaya, A. S., \& Putri Y. M. (2013). Keperawatan Medikal Bedah 1. Yogyakarta: Nuha Medika

Wong, D. L., Hockenberry, H. M., Wilson, D., Winkelsein, M. L., \& Schwatrz, P. (2009). Buku Ajar Keperawatan Pediatrik. (edisi 6). (Monika Ester penterjemah). Jakarta: EGC

World Health Organization. (2015). Obesity: Preventing and Managing the Global Epidemic 
Zamzani, M., Hadi, H., \& Astiti, A. (2016). Aktivitas Fisik Berhubungan dengan Kejadian Obesitas. Jurnal Gizi dan Dietetik Indonesia, 4(3), 123-128 